\title{
THE DISTRIBUTION OF OCTOPUS VULGARIS LAMARCK IN BRITISH WATERS
}

\author{
By W. J. Rees, D.Sc. \\ British Museum (Natural History)
}

(With Plates I-III and Text-figs. I-3)

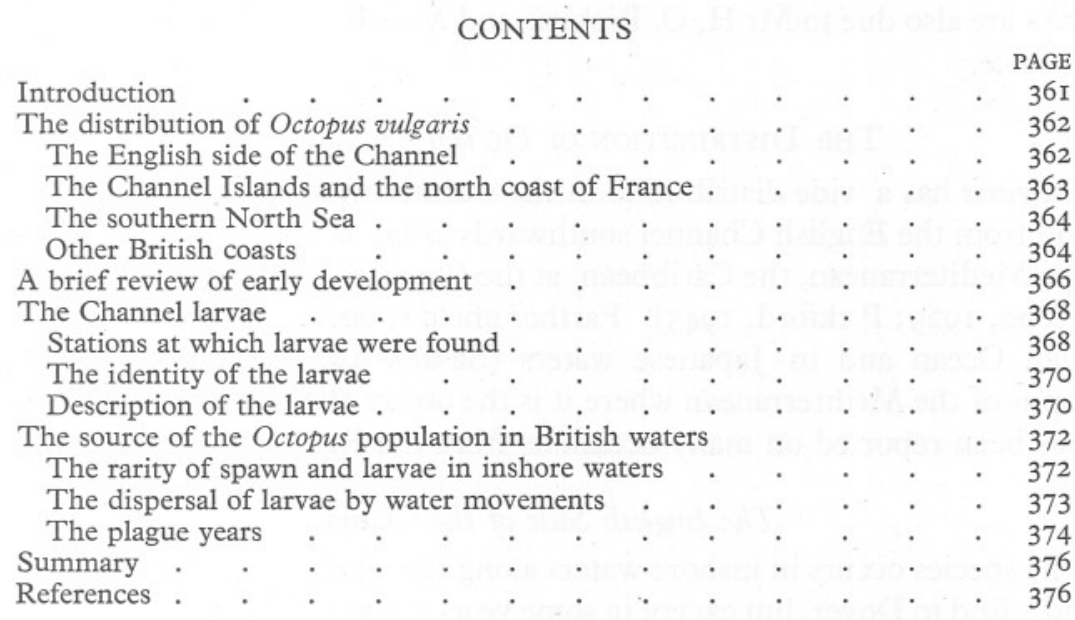

\section{INTRODUCTION}

Octopus vulgaris Lamarck is usually regarded as a Lusitanian member of our fauna. It is found on the south coast of England, and, as E. J. Allen noted (Marine Biol. Assoc., I93I, p. 278) 'generally only a few specimens are taken during the summer months, but it varies greatly in abundance in different years'. In I899-I900 there was a great plague of Octopus all along the south coast of Devon and Cornwall, which served to accentuate the rarity of the species in other years. This phenomenon was the subject of a report by Garstang (1900). Another puzzling feature was the paucity of records of Octopus larvae and spawn in our inshore waters which at once suggested that the species rarely breeds on the English coast. If so, how was the population maintained from year to year and whence did the larvae or adults come? During the recent cruises of the M.Y. Manihine planktonic larvae of $O$. vulgaris have been found for the first time in fairly substantial numbers in the Channel. These yield much information on the early larval Octopus, and also I believe on its distribution in the Channel and southern North Sea. 
In order to present as complete a picture as possible, I have thought it desirable to review earlier records for the south coast of England, the Channel Islands and the French coast, the southern North Sea and other British records.

Acknowledgements are due to Major H. W. Hall, M.C., whose interest in marine biology led to the very generous loan of the M.Y. Manihine for this and other investigations in the English Channel.

I am also especially indebted to $\mathrm{Dr} \mathrm{H}$. W. Parker for facilitating my work in various ways. I wish to thank: $\mathrm{Mr} \mathrm{D}$. W. Tucker for the care he took in the preservation of some of the larvae, Dr D. P. Wilson for the use of the photograph on Plate I, and Mr G. L. Wilkins for his admirable drawings. My thanks are also due to Mr H. O. Ricketts and Miss B. Skramovsky for technical assistance.

\section{The Distribution of OCTOPUS VULGARIS}

$O$. vulgaris has a wide distribution in the warmer waters of the Atlantic. It is found from the English Channel southwards as far as the Cape of Good Hope, in the Mediterranean, the Caribbean, at the Canaries, the Azores and Bermuda (Robson, I929; Pickford, 1945). Farther afield it occurs at some places in the Indian Ocean and in Japanese waters (Sasaki, I929). It is the common octopus of the Mediterranean where it is the object of fisheries at many places. It has been reported on many occasions from the Red Sea.

\section{The English Side of the Channel}

The species occurs in inshore waters along the whole of the south coast from Land's End to Dover, but except in some years it is seldom common. According to Forbes \& Hanley (1853, p. 210) the first British record was from Dover; later in I84I it was taken at Plymouth by Robert Ball. Lee (I875) mentions a specimen captured in a lobster pot at Eastbourne, one from Mevagissey and another from Brighton; all these were exhibited at the Brighton Aquarium in the days when Octopus was a star attraction. Other sporadic records indicate that the species is found along the whole coast.

In the years I899-I900, as mentioned above, there was a plague of Octopus along the south coast of Devon and Cornwall. According to Garstang (I900), Octopus, which had been scarce in the neighbourhood of Plymouth since the opening of the Laboratory there, became more plentiful from January I899 onwards. During 1900 the increase reached the dimensions of a plague which had a disastrous effect on the crab and lobster fisheries along the whole coast of Devon and Cornwall. Not only did the Octopus invade the crab pots, but they were so numerous, in September 1900, as to drive large crabs out of their normal haunts below low-water mark on to the intertidal region in Plymouth Sound. In the same year Allen \& Todd found several Octopus 'nested' on the shore of Salcombe Estuary, and Garstang records a minute 
Octopus larva in a tow-netting in the same estuary in August. Garstang was inclined to attribute the startling increase of Octopus to the warm summers and the mild winters experienced from 1893 onwards, these providing favourable conditions for a warm-water animal. This view is discussed in relation to distribution problems below (p. 374).

Minor plagues appear to have occurred at Brighton in I9I3 and I922 (Robson, I929), and in the summer of 1948.

Lee (I875, p. 64) records an Octopus with its spawn taken in a dredge off Brighton in March I874. Apart from occasional spawning under artificial conditions in public aquaria, and the two records mentioned, I can find no other records of spawning or of larvae in our inshore waters. Crawshay (I9I2), in his thorough report on the fauna of the Outer Eddystone, and F. S. Russell, in numerous plankton reports from the Plymouth area, mention neither spawn nor larvae.

Another interesting feature of Octopus distribution on the English coast is the absence of nested specimens at low water on the shore, except in plague years.

\section{The Channel Islands and the North Coast of France}

Octopus is fairly common on the shore at low water in the Channel Islands and has been reported on numerous occasions.

Dautzenberg \& Fischer (I925, p. I) state that the species is common on both west and north coasts of Finistère. In the Bay of St Malo, Dautzenberg \& Durouchoux (1913, p. 7) record its occurrence in shallow water in the Zostera beds or lurking under large stones or in crevices of rocks, presumably on the shore. They say that its presence when nested is often indicated by masses of bivalve shells of molluscs on which it feeds. ${ }^{1}$

On the Normandy coast it is recorded for the north and east coasts of the Cherbourg peninsula by Kerville (I898, I90I). He found small specimens on the shore between tide marks on the beach at St Martin, to the west of Omonville la Rogue, as well as specimens in lobster pots. In this area the species is regarded as more or less common. On the east coast of the peninsula, Kerville states that it is very common in holes in rocks and under large stones in the region of Grandcamp-les-Bains. A large specimen was caught between tide marks on the Iles Saint-Marcouf.

Still further east, Loe \& Raeymaekers (1885, p. 212) record Octopus from the Bay of the Somme, where it is sometimes thrown up on the beach after storms and frequently taken by fishermen in their nets.

Giard (1885, p. 302) also mentions Octopus in the eastern end of the Channel from Tour de Croy and Pointe à Zoie, Audresselles. It appears that it is very common under stones from April to September.

The plague year I899, in particular, is mentioned by Kerville (I90I). The

${ }^{1} \mathrm{Mr}$ A. E. Salisbury informs me that in the Channel Islands these remains consist almost entirely of Paphia rhomboides (Pennant). 
species was then very abundant in the region of Omonville la Rogue. Dautzenberg \& Fischer (1925) also mention for Finistère that the species was very abundant in some years. Garstang gives additional information, derived mainly from newspaper reports, about the plague on the French coast in which Octopus appears to have been as abundant in 1899 as in 1900 - unlike the situation on the English coast where the peak as regards numbers was reached in I900. It appears that the infestation, if it may be so termed, affected the whole coast of Finistère and the Channel Islands, and extended eastwards at least as far as Omonville la Rogue. As on the English coast the lobster and crab fisheries were ruined for the time. ${ }^{1}$

Two features emerge from this survey. The species is normally found close inshore, even nesting at low water on the shore, a habit which occurred on the English coast during 1900 . The abundance of Octopus reached the dimensions of a plague about a year earlier than it reached its peak on the English side. The significance of these points is discussed below (p. 375).

\section{The Southern North Sea}

Records of Octopus in the southern North Sea are few and the species appears to be rare. Robson (I929) mentions a specimen from the River Crouch, Essex: this is the only record that can be verified from the east coast of England. For the Belgian coast Adam (I933) has shown that many of the older records are not reliable, but quotes an early record by van Beneden (I883). Adam reported a specimen from Ostende and another taken between Blankenberghe and Orfordness. As Adam remarks, the capture of only two specimens during an intensive survey of the southern North Sea, between 50 and $53^{\circ} \mathrm{N}$., is an indication of the rarity of the species in the area.

Tesch (I908), mainly quoting earlier records, mentions several specimens from the Dutch coast, but some of these need verifying. Only three specimens are known from the German coast. One, labelled 'Westerems (Rottum)', is in the Leipzig Museum, and another in the Berlin Museum is from Heligoland. The third was reported from the Borkum area by Hertling (1936).

There are no records from the Danish, Swedish and Norwegian coasts.

\section{Other British Coasts}

Records of Octopus from other British coasts are few and most of them have been discounted by Grimpe (I925) and Robson (I929). The species has been confused with Eledone cirrosa which normally has a single row of suckers on

1 Since this part of the paper was written, I have been privileged to examine a file of newspaper cuttings kept by Mr R. Winckworth. It appears that there was a plague of Octopus on the coast of Finistère in I 922 with the usual disastrous effect on the shell-fisheries (The Times, 27 March I922). According to one report the crabs were seeking refuge on the shore in July of that year (Daily Mail, I I August I922). 
each arm. In the latter the suckers may appear to be biserial, as in Octopus, particularly in contracted specimens. Occasionally an abnormal Eledone is found in which the suckers are irregularly biserial (Gravely, I908).

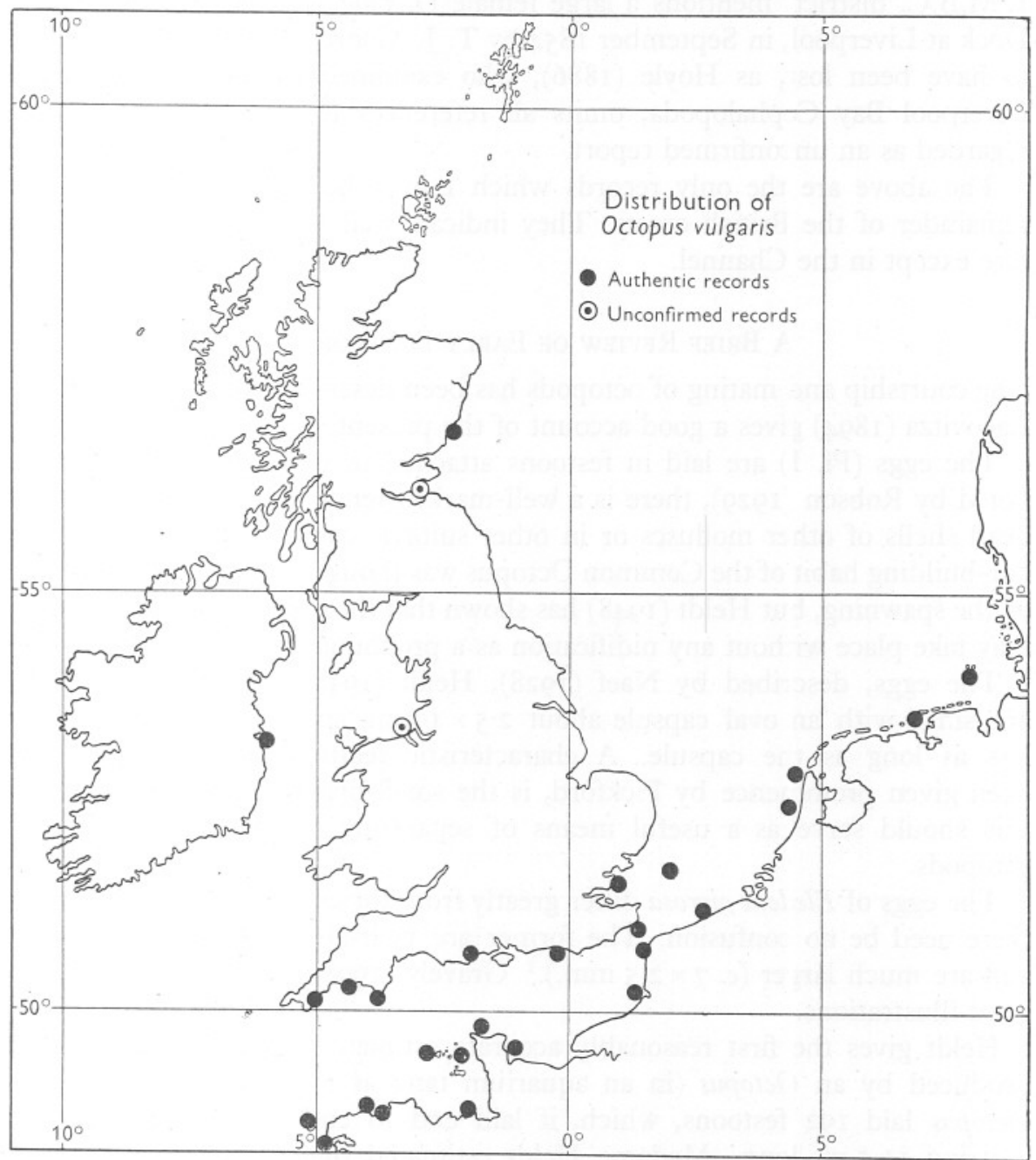

Text-fig. I. The distribution of $O$. vulgaris in North European waters. Token records only are given for the English Channel but all records (usually referring to one or two specimens each) are plotted for other areas.

Early records from the Firth of Forth cannot be verified, but Stephen (I937) confirms a record of a very juvenile specimen, of $\mathrm{I} \cdot 5 \mathrm{~cm}$. in mantle length, picked up on the beach at Montrose in I893.

Nearly all of the old Irish records are also doubtful, but the specimens reported by Haddon (I886) from Dublin Bay are in the Museum of Trinity 
College, Dublin. These were re-examined by Massy (I909, p. 6), who confirmed that they were Octopus vulgaris.

Darbisher (1886, p. 245), in his report on the molluscan fauna of the L.M.B.C. district, mentions a large female $O$. vulgaris, taken in the Albert Dock at Liverpool, in September I854 by T. J. Moore. The specimen appears to have been lost, as Hoyle (I886), who examined the remainder of the Liverpool Bay Cephalopoda, omits all references to it. This can only be regarded as an unconfirmed report.

The above are the only records which I have been able to find for the remainder of the British coasts. They indicate that $O$. vulgaris is extremely rare except in the Channel.

\section{A Brief Review of Early Development}

The courtship and mating of octopods has been described for several species: Racovitza (1894) gives a good account of the present species.

The eggs (Pl. I) are laid in festoons attached to rocks or stones, and, as noted by Robson (1929), there is a well-marked tendency to deposit them in dead shells of other molluscs or in other suitable cavities. The 'nesting' or lair-building habit of the Common Octopus was thought to be an essential part of the spawning, but Heldt (1948) has shown that the laying of batches of eggs may take place without any nidification as a preliminary.

The eggs, described by Naef (1928), Heldt (1948) and Pickford (1950), are small with an oval capsule about $2.5 \times \mathrm{I} \mathrm{mm}$. and the stalk is more or less as long as the capsule. A characteristic feature, which has recently been given prominence by Pickford, is the small oval swelling on the stalk; this should serve as a useful means of separating the species from other octopods.

The eggs of Eledone cirrosa differ greatly from those of Octopus, with which there need be no confusion. The former are pear-shaped with a short stalk and are much larger $\left(c .7 \times 2.5 \mathrm{~mm}\right.$.). ${ }^{1}$ Gravely (1908, Pl. II, figs. 7,8$)$ gives good illustrations.

Heldt gives the first reasonably accurate estimate of the number of eggs produced by an Octopus (in an aquarium tank at Salammbô, Tunis). The Octopus laid 192 festoons, which, if laid end to end, would have formed a string II $.5 \mathrm{~m}$. long. Madame Heldt estimated that there was a total of I50,000 eggs.

At Naples, Lo Bianco (1909, p. 654) records that spawning in the aquarium takes place from May to September, and Heldt mentions October as the time of spawning of her specimen. Tandy's eggs from Florida were found in August, and Pickford (1950) mentions eggs laid in March and August from the same locality. In the Channel, as already stated, Lee (1875) records an Octopus

\footnotetext{
1 Naef (1928) gives 6-9 mm. as the length of Eledone eggs.
} 
with its eggs in March I874, while Garstang's larva from Salcombe was found in August and must have come from eggs laid not later than June or July. Portmann (1933), working at Banyuls, found eggs in various phases of development and concluded that they had been developing for about 8 days. They hatched on 4 September, about I 8 days after spawning. On the other hand, Naef (1928), working at Naples, found that the larva took 28 days to develop. Portmann attributed the rapid development of his larvae to the high temperature of his aquarium $\left(24-25^{\circ} \mathrm{C}\right.$.). In view of much lower temperatures in the Channel, development there may be expected to take at least a month, possibly even longer, and in breeding areas larvae are probably hatched from April or May until the end of September.

According to Lee (I875): 'At this early stage of its existence the young Octopus seeks and enjoys the light.' But Portmann states that in his larvae phototropism was less marked than in Loligo. This author admits a great mortality among the developing eggs, but assumes it to be due to the absence of the parent, and to the inadequate aeration of some of the eggs.

The early development of the larva within the egg has often been studied. Naef (I928) and Portmann (I933) sum up our knowledge of this development, and the latter states that the fully developed larva possesses a small external vitelline sac at its birth, its contents being absorbed soon after, or sometimes even before, hatching.

Even before hatching the minute Octopus is provided with numerous groups of small bristles (Köllikersche Bundel), scattered over the whole outer surface, and Naef considers that their function is to assist the larva to leave the egg. He states: "These spines or bristles are used when the egg hatches, as seen by me in Octopus vulgaris. The hatching occurs with the posterior end in front, as is usual in dibranchiate cephalopods, the opening is rather small, and is situated on the thicker end of the egg capsule; the exit is the same place through which the spermatophores entered, that is, the micropyle. Through this small opening the animal has to liberate itself, this process being helped by the spines which act as hooks. Sometimes the embryo is wrongly placed in the egg capsule, that is, with the oral end towards the opening, in which case it becomes impossible for it to leave the egg capsule and it dies, as it is impossible for it to turn round inside the egg and the spines are now directed in such a way as to face the opening, and so prevent the animal from leaving the capsule.' Portmann disputes these conclusions and points out that in some larvae ( $7 \mathrm{hr}$. after liberation) the bundles were still hidden beneath the skin. Querner (1926), on the other hand, considers that these structures indicate that the ancestors of cephalopods were provided with bristles similar to those of annelids. Whatever purpose these bristles serve during liberation, it appears that they help to keep the animal afloat and later develop into the warts which are so characteristic of the skin of the Octopus.

The post-embryonic life of the larva has been little studied. Naef (I923, 
text-figs. 400, 409) gives a thumb-nail sketch of the newly emerged Octopus, of about $\mathrm{I} .5 \mathrm{~mm}$. in ventral mantle length, and of some slightly older larvae of about $\mathrm{I} .8 \mathrm{~mm}$. in ventral mantle length. He records that larvae of this size are fairly common in the plankton in the Gulf of Naples during the summer and autumn. Naef further remarks that older juvenile stages are not found in the plankton and assumes that they settle on the sea floor, undergoing metamorphosis buried in the sand or detritus, and are found again when they are much larger and have assumed the shape of the adult.

\section{The Channel Larvae}

Naef's view of a very brief plankton stage in the life of an Octopus has been generally accepted for this species, and Portmann, for example, remarks: 'Il se peut donc que la vie d'Octopus ne comprenne pas une première étape pélagique et que la larve mène déjà la vie de la pieuvre adulte.' It was therefore quite unexpected that Octopus larvae should be found in the plankton in the middle of the Channel and that they should still be planktonic at a much larger size than mentioned by Naef.

Octopus larvae were found at the stations enumerated below. These are shown in the map in Text-fig. 2 as black circles.

\section{Stations at which Larvae were Found}

St. 47. 31. viii. $48.49^{\circ} 55^{\prime} 20^{\prime \prime}$ N., $02^{\circ} \circ 8^{\prime}$ W. Sounding $109 \mathrm{~m}$.; N roo B, 90- $\mathrm{m}$. Four larvae,

St. 48. 3I. viii. $48.49^{\circ} 52^{\prime}$ Io $^{\prime \prime}$ N., $02^{\circ}$ IO $^{\prime}$ Io" $^{\prime \prime}$ W. Sounding $78 \mathrm{~m}$.; N roo B, $73-0 \mathrm{~m}$. Seven larvae.

St. 49. 31. viii. $48.49^{\circ} 50^{\prime}$ N., $02^{\circ} 08^{\prime} 45^{\prime \prime}$ W. Sounding $73 \mathrm{~m}$.; N roo B, 69-0 m. Five larvae.

St. 50. 3I. viii. $48.49^{\circ} 49^{\prime}$ N., $02^{\circ} 28^{\prime} 45^{\prime \prime}$ W. Sounding I 27 m.; N IO0 B, I00-0 m. Four larvae.

St. 5I. 3I. viii. $48.49^{\circ} 50^{\prime} 20^{\prime \prime}$ N., $02^{\circ} 3 I^{\prime} 40^{\prime \prime}$ W. Sounding I 55 m.; N roo B, $93-0$ m. Four larvae.

St. 60. 20. viii. 49. $50^{\circ} \mathrm{N}$., $\mathrm{I}^{\circ} 54^{\prime} \mathrm{W}$. Sounding $75 \mathrm{~m}$.; N roo B, $46-0 \mathrm{~m}$. Seven larvae.

St. 6I. 2I. viii. $49 \cdot 50^{\circ} 04^{\prime}$ N., I ${ }^{\circ} 57^{\prime}$ W. Sounding $60 \mathrm{~m}$.; N I00 B, $46-0 \mathrm{~m}$. Thirteen larvae.

St. 62. 2I. viii. 49. $50^{\circ} 06^{\prime} 30^{\prime \prime}$ N., I $I^{\circ} 49^{\prime} 30^{\prime \prime}$. W. Sounding $57 \mathrm{~m}$.; N roo B, $43-0 \mathrm{~m}$. Ten larvae.

St. 63. 2I. viii. 49. $50^{\circ} 10^{\prime} 30^{\prime \prime}$ N., $I^{\circ} 55^{\prime} \mathrm{W}$. Sounding $55 \mathrm{~m}$.; N $100 \mathrm{~B}, 53-0 \mathrm{~m}$. Two larvae.

St. 64. 2I. viii. $49.50^{\circ} \mathrm{I}^{\prime} 30^{\prime \prime} \mathrm{N}$., I $\mathrm{I}^{\circ} 47^{\prime} 30^{\prime \prime} \mathrm{W}$. Sounding $55 \mathrm{~m}$; N IOO B, $5 \mathrm{I}-\mathrm{O} \mathrm{m}$. One larva.

St. 71. 30. viii. $49.49^{\circ} 58^{\prime} 0^{\prime \prime}$ N., $2^{\circ} 48^{\prime} 30^{\prime \prime}$ W. Sounding 66 m.; N 100 B, $29-0 \mathrm{~m}$. Three larvae.

St. 72 . 30. viii. $49.49^{\circ} 47^{\prime}$ N., $2^{\circ} 42^{\prime} 20^{\prime \prime}$ W. Sounding I 24 m.; N. 100 B, 56-O m. Seven larvae.

St. 73. 30. viii. $49.49^{\circ} 37^{\prime} \mathrm{N} ., 2^{\circ} 30^{\prime} 30^{\prime \prime} \mathrm{W}$. Sounding $64 \mathrm{~m}$; $\mathrm{N}$ I00 $\mathrm{B}, 26-0 \mathrm{~m}$. Two larvae. 


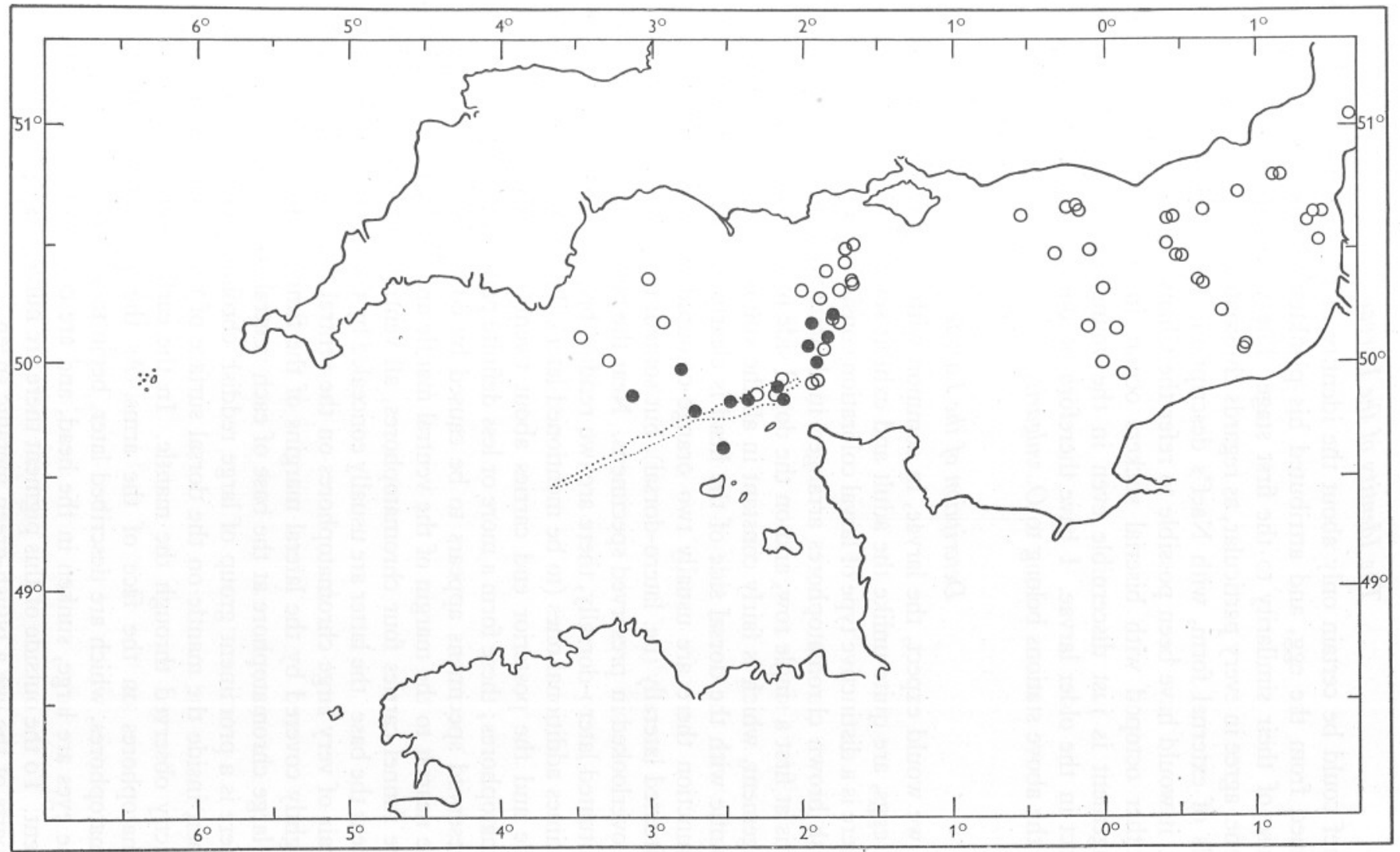

Text-fig. 2. The distribution of Octopus larvae (black circles) as found during the cruises of the M.Y. Manihine in the Channel during the summers of 1948 and 1949. Negative stations (open circles) are also plotted to show the areas worked during the investigations. 


\section{The Identity of the Larvae}

Naef could be certain only about the identity of his first stage, which he obtained from the egg, and attributed his planktonic larvae to $O$. vulgaris because of their similarity to the first stage. The youngest larvae from the Channel agree in every particular, as regards chromatophore pattern and other details of external form, with Naef's description. Quite apart from Naef's work, it would have been possible to refer the Channel larvae to $O$. vulgaris. No other octopod with biserial suckers occurs in the Channel, and this arrangement is just discernible even in the youngest larvae, and is quite distinct in the older larvae. I have therefore no doubt that the larval series from the above stations belong to $O$. vulgaris.

\section{Description of the Larvae}

As we would expect, the larvae, in common with other Octopodinae with small eggs, are quite unlike the adult and exhibit several characteristics.

There is a distinctive type of larval coloration consisting of large, prominent, reddish brown chromatophores arranged in definite patterns. On the arms, there is at first a single row, and on the dorsal side of the head a symmetrical arrangement, which is fairly constant in all the younger stages. The junction of mantle with the dorsal side of the head is clearly visible, and just behind this junction there are usually two orange-coloured chromatophores; these are situated laterally (i.e. latero-dorsal), but sometimes they are faint and apt to be overlooked in preserved specimens. Near the posterior end of the body, also situated latero-dorsally, there are two reddish brown chromatophores and sometimes additional ones (to be mentioned later). The ventral surface of the mantle and the posterior end carries about twenty distinct reddish brown chromatophores; these form a more or less definite pattern, but its irregularity in preserved specimens appears to be caused by contraction of the mantle. Those nearest to the margin of the ventral mantle are usually in a row of six.

The funnel carries four chromatophores, all ventral, two near the tip and two near the base; the latter are usually concealed by the mantle margin. There is a pair of very large chromatophores on the ventral head, one on either side or slightly covered by the lateral margins of the funnel, and there is also an extra large chromatophore at the base of each ventral arm.

There is a prominent group of large reddish chromatophores, six to ten in number, inside the mantle on the dorsal surface of the viscera; these can be distinctly observed through the mantle. In the earliest stages there are no chromatophores on the face of the arms. As the larva grows, additional chromatophores, which are described later, begin to appear.

The eyes are large, sunken in the head, and are covered with dark brown pigment. To the outside of this pigment there are numerous iridocytes, which give parts of the eye a bluish-green metallic sheen. 
The arms are quite short in early stages (P1. II, figs. I, 2). They are all about the same length and have a thin whip-like terminal portion.

The youngest Channel larvae were provided with three or four primary uniserial suckers, each with a diameter of $0.175-0.2 \mathrm{~mm}$. Larvae of $2 \cdot 25-3.45 \mathrm{~mm}$. (mantle length) had primary suckers of $0.25-0.3 \mathrm{~mm}$. in diameter. In larger larvae of $3.75-6.0 \mathrm{~mm}$. the diameter of primary suckers reached $0.35-0.55 \mathrm{~mm}$. and those of the first part of biserial suckers, $0.25-0.5 \mathrm{~mm}$.

The web is poorly developed, showing no sign of differentiation in depth. Only the rims of the jaws appear to be chitinized.

The newly hatched Octopus is covered on head, mantle and arms with numerous groups of bristles; but in the preserved specimens the latter are not easily seen, because they tend to disappear in formalin. They are believed, apart from whatever role they may play in the release of the larvae from the egg, to have some significance in the planktonic life of the animal (Naef, I928; Adam, 1937). In the Channel larvae they are present at all stages up to the largest of $6 \mathrm{~mm}$. in ventral mantle-length. In the latter, they appear to be in process of being transformed into the warts of the adult.

In the youngest larvae the mantle width is frequently greater than the mantle length. Between $\mathrm{I} \cdot 8$ and $2 \cdot 4 \mathrm{~mm}$. (that is, in ventral mantle length) the length overtakes the width, and beyond this size the mantle length is always greater than the width. This is clearly indicated in Text-fig. 3, where the mantle width is expressed as a percentage of the mantle length. There is a suggestion too that the mantle is more elongated during its growth between 3 and $4.5 \mathrm{~mm}$. than when it grows beyond this stage. Unfortunately the number of larvae of this size are too few to give adequate results and it must be remembered that the mantle itself is capable of much variation. ${ }^{1}$

The following brief description applies to the largest larva found (P1. III). This specimen has already acquired many adult characters, such as the proportions of the mantle and head, but the arms are still quite short. These are subequal, and in the contracted state are about $7 \mathrm{~mm}$. long. The web, too, is subequal and reaches as far as the first row of double suckers. On the oral face of the arms there are no chromatophores on the suckers in the proximal web region, but reddish brown ones occur between the biserial suckers beginning with the first pair (Pl. III, fig. 8). Some suckers on the arms are also developing chromatophores around their rim, in the same way as illustrated by Adam (1937, fig. $30 \mathrm{H}$ ) for his Octopus larva from the coast of Brazil.

The outer surfaces of the arms carry a double row of evenly spaced chromatophores, and, in addition to these, two further rows are developing, one on either side of the arms; those on the dorsal and dorso-lateral arms are

\footnotetext{
1 The ventral mantle length is used by all workers on Cephalopoda and is regarded as a more reliable measurement than those of the head, arms and funnel. It is for this reason that I have refrained from giving measurements of the head and arms, but the proportions in larvae at different stages can be seen from the drawings.
} 
better developed than those on the ventral arms. There are also light orangecoloured chromatophores developing in the surface skin of the head and web. Some on the former are difficult to see because they are situated over the more deep-seated chromatophores of the head region. In this specimen there are also four reddish brown surface chromatophores on the surface of the mantle, at its junction with the head.

Intermediate younger stages are illustrated in Pl. I.

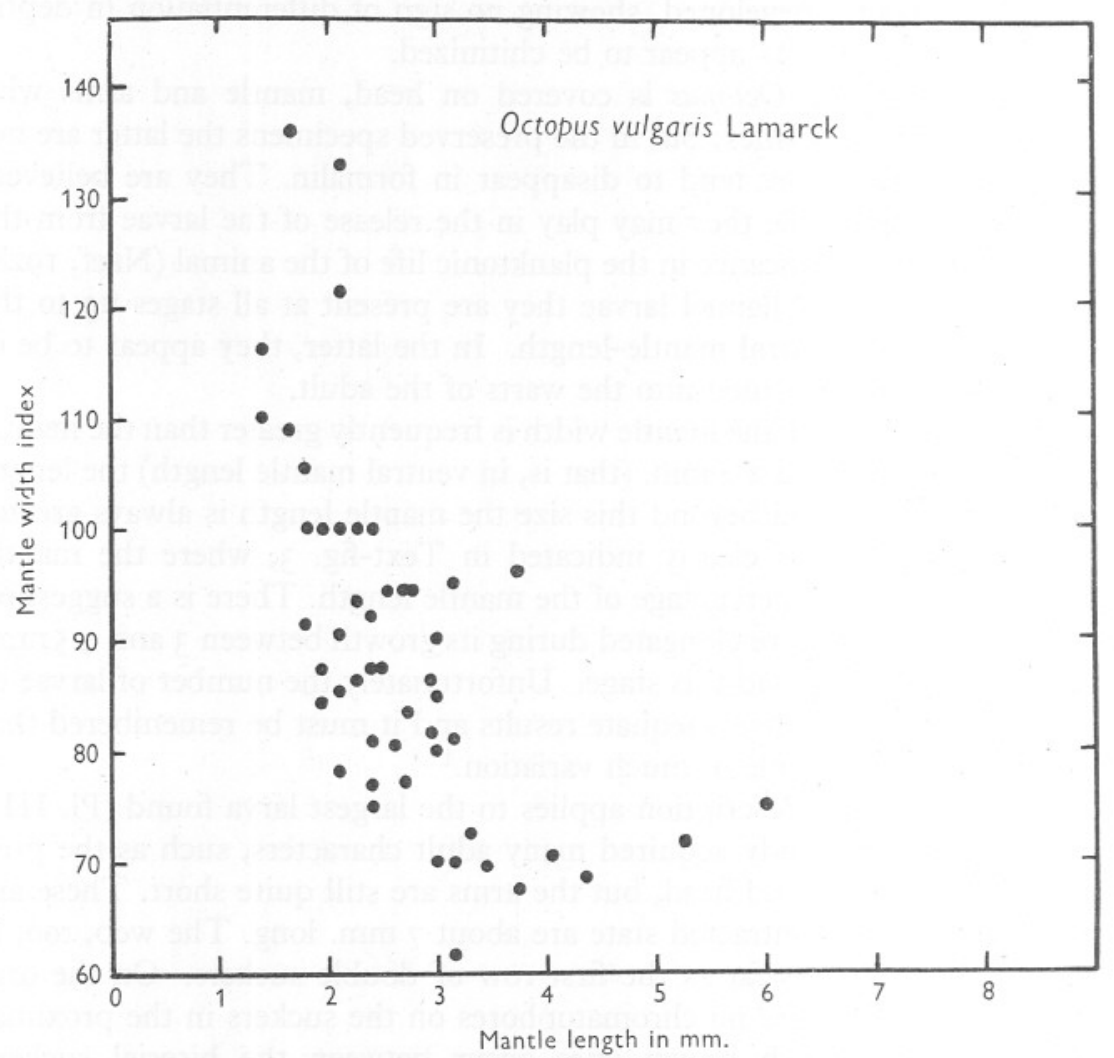

Text-fig. 3. The relation of mantle length to mantle width in the Channel larvae. The mantle width is expressed as a percentage of the mantle length.

\section{The Source of the Octopus Population in British Waters}

\section{The Rarity of Spawn and Larvae in Inshore Waters}

It has already been indicated that the eggs of Octopus have been found only on one occasion on our coast. This alone is insufficient proof of absence of regular breeding, because the eggs of Eledone are almost equally scarce and both species probably lay their eggs in places which are almost inaccessible to the ordinary dredge or trawl. The absence of any report of planktonic larvae, 
except in the abnormal year I900, during the whole existence of the Plymouth Laboratory is much more significant and may be regarded as reasonable proof that the species breeds here only under abnormal conditions. Eledone, as is well known, breeds all round our coast but its larvae are rarely found in the plankton for a very different reason, so I believe. Its eggs are large, 6-9 mm. in length, so that the embryo is able to complete its larval development before hatching. As Naef (I923) has shown, the young Eledone already possesses all the characteristics of the adult form, and so on liberation is nearly ready to settle down to a benthic existence.

It is therefore extremely doubtful whether the Octopus is able to maintain a breeding stock on the English side of the Channel, and the most likely explanation is that the population is an immigrant one, maintained each year by an influx of young from the south, reinforced in exceptional years by limited local breeding.

\section{The Dispersal of Larvae by Water Movements}

The duration of the planktonic life of the young Octopus is certainly not short as assumed by Naef. Judging from my larvae the period could not be less than I month and might even be 3 months, under exceptional circumstances. This moderately long planktonic life enables us to consider dispersal by currents and other water movements. In this connexion, the work of Carruthers (I927) with drift bottles in the English Channel proves very interesting, especially as many of his bottles were released in approximately the area in which the larvae were found. Most of the larvae appear to have been taken in the mid-water and surface layers with open nets.

Although the larvae are not strictly comparable to either surface or bottom bottles, the experiments of Carruthers are of sufficient interest to indicate in a broad way the future movements of larvae. I have not considered the movements of surface bottles very closely, because they may have been unduly influenced by wind drift, and the bottom bottles are probably more reliable for our purpose.

There is an easterly set along the north coast of Finistère which impinges on the Manche coast and swings northwards past the Channel Islands. This is borne out by both surface and bottom bottles. To the north of the Channel Islands, as Carruthers states, 'there seems to be in longitude $2^{\circ} \mathrm{W}$. (approximately) a parting of the ways in respect of the movements of the bottom water. To the north of $50^{\circ} \mathrm{N}$. latitude there appears to be a west-going bottom set, whereas south of this parallel there is a set going in an easterly direction'. This is the very area in which the Octopus larvae occur; many of the latter are obviously recently hatched, some being no longer in mantle length than specimens just released from the egg. The hydrographic conditions indicate that they come from the south, that is, the Channel Islands, the Manche coast, and possibly also the north coast of Finistère. These areas are undoubtedly 
important, if not the main, breeding grounds of Octopus in the Channel, and from them the species is distributed westwards to Lyme Bay and beyond, and eastwards to Dover and also occasionally into the North Sea. It is also possible that Lyme Bay may draw some of its Octopus from a more south-westerly source, as may Cornwall and the Plymouth area. We do not know whether Octopus reaches Cornwall from the east in 'Channel water', or from across the Channel, in one of the bodies of water known to penetrate into the Channel occasionally from Ushant and the Biscay region (see Russell, I939). As far as I am aware, no larvae have been taken in this outer part of the Channel, and it may be that they become benthic at some distance from our coast. Winckworth (I928), discussing the scarcity of male specimens, states 'the scanty evidence available points to the probability that mating takes place in deeper water after which the females migrate towards the shore to spawn'.

There may also be subsidiary breeding areas along the French coast between the Cherbourg Peninsula and Boulogne, but available evidence indicates that Octopus is much less abundant there than it is to the west of the Peninsula.

The conditions found by Carruthers (I927) were those existing in July I924, and as Russell has shown (1939) the water circulation in the Channel is very variable. These fluctuations will regulate the number of larvae distributed to various points of our coastal areas, so that Brighton, for instance, may have a dearth of Octopus during a year when they are fairly common in Lyme Bay.

I am inclined to regard the easterly set along the north coast of Finistère, carrying larvae to the coast of the Manche and the Channel Islands, as a very important factor in maintaining the stock of Octopus in the Channel, as the larvae would reinforce the local stock at this northern limit for breeding. As temperature is undoubtedly the most important factor controlling breeding in this area, a succession of years of low sea temperature would mean that few larvae would hatch out and reach maturity. These reinforcements would help to maintain the stocks.

\section{The Plague Years}

The plague years 1899 and 1900 were probably due to a combination of factors, all favourable to the multiplication and spread of the species in the Channel.

As already mentioned, temperature is undoubtedly a controlling factor and, as Garstang believed, the abnormal conditions probably began in 1893, an exceptional year, during which 'Under the influence of the great heat the temperature of the Channel waters rose continuously until in August it had attained a point unprecedented for a quarter of a century.... In June the tow-nets were crowded with Salps, while towards the latter end of August they were almost choked by masses of living Radiolaria... . Even the bottom fauna was influenced, as was shown by the extraordinary abundance in the Sound. ...' 
(Garstang, I894). The French coast, too, was influenced by the exceptional conditions, as there was a heavy fall of oyster spat in that year(Herdman, I893). Later (I900) Garstang adds: 'The warm summers and mild winters which we have experienced during the past few years (i.e. since I893) have also provided the conditions most suitable to a warm water animal and have favoured its residence in our inshore waters.'

The fauna of the north-west coast of France and the Channel Islands is much richer in southern species than the corresponding coast of Britain. This may be partly accounted for by a slightly higher temperature, but the hydrographic conditions undoubtedly play a big part. Unfortunately, we know so little about the penetration of various bodies of water, from the mouth of the Channel and the Biscay area, along the south side of the Channel. The relative abundance of the commoner littoral forms on the two sides of the Channel, has been the subject of a report by Fischer-Piette (1936).

On the French side of the Channel there appears to have been a gradual building up of stocks during these years, culminating in the plague of I899. It is also possible that there may have been large-scale immigration of larvae from the west coast of France, in the years immediately prior to I899. The crab and shell-fisheries were ruined by the hordes of hungry Octopus and fishermen were forced to seek alternative employment. On the English side there was no indication of a building up of the population before I899, but from January of that year the species became increasingly plentiful, reaching its greatest abundance in I900, causing widespread damage to the shellfisheries by the end of the year. Garstang thought that the plague on the English coast was caused by dearth of food on the French side, resulting in 'migrations outwards from the overcrowded centres of multiplication'. This view is probably correct because a great many of the Octopus were large, reaching a span of $7 \mathrm{ft}$. from tip to tip of outstretched arms. These could not be less than 3 or 4 years old, and before 1899 there was no indication of an increase in the Octopus population.

The abundance of Octopus at Brighton in I9I3 appears to be the outcome of favourable hydrographic conditions concentrating numerous larvae in the area in an earlier year. This was likely to be the year I9I I when a warm fine summer was experienced. I have no information on the prevalence of the species in Brittany and the Channel Islands for these years.

The second minor plague at Brighton, late in I922, was obviously similar and probably linked with the more serious plague on the coast of Finistère in 1922 .

In May I948 a plague of young Octopus was reported at Brighton by the Press. These appear to have been mostly small specimens and may reasonably be regarded as brood of 1947, another favourable year for breeding.

Quite recently, January I950, an increase of Octopus was reported from the Channel Islands, with the usual complaint from fishermen that they were 
devouring the shellfish. ${ }^{1}$ The exceptionally warm summers we have experienced in recent years have undoubtedly favoured the increase of Octopus.

The finding of a young Octopus on the beach at Montrose in Scotland can probably be attributed to the exceptional hydrographic conditions in the year 1893. In order to reach this point, the larva must have had an extended planktonic life in the North Sea. This raises the question whether benthic cephalopods with planktonic larvae are able to prolong their life in the plankton, in the same way as annelids, when the factors which induce 'settlement' are absent. It is possible that the Dublin Bay specimens were also carried beyond their normal range because of some unusual hydrographic conditions.

\section{SUMMARY}

In Britain Octopus vulgaris occurs on the Channel coast and only very rarely on other coasts. In Brittany and the Channel Islands it frequently makes its lair at low water, but on the English side of the Channel it does not come so close inshore except in abnormal years of high sea temperatures.

The discovery of Octopus larvae of various sizes, from newly hatched to $6.0 \mathrm{~mm}$. (mantle length), in plankton hauls taken to the north of the Channel Islands, proves that the species has a much longer planktonic life than hitherto supposed.

The water circulation in the English Channel, as indicated by drift bottles, is admirably suited to the dispersal of larvae to our shores from breeding centres on the coasts of Brittany and the Channel Islands.

Thus our Octopus population is believed to be an immigrant one maintained each year by an influx of larvae, and the vagaries of the water movements each year would account for the fluctuations in the abundance of the species.

Periodic plagues of Octopus appear to be due to good weather conditions over a succession of years causing a higher sea temperature, ensuring better breeding conditions for a warm water animal at the northern limit of its breeding range.

\section{REFERENCES}

ADAM, W., I933. Notes sur les céphalopodes. III. Les Céphalopodes du sud de la mer Nord. Bull. Mus. Roy. Hist. Nat. Belg. T. 9, No. 46, 45 pp.

_ 1937. Résultats scientifiques des croisières du navire-école Belge 'Mercator'. IV. Cephalopoda. Mem. Mus. Roy. Hist. Nat. Belg., Ser. II, Fasc. 9, pp. 43-82.

Allen, E. J. \& Todd, R. A., I900. The fauna of Salcombe Estuary. Fourn. Mar. Biol. Assoc., Vol. 6, pp. I5I-217.

BeLCHER, T. E., I922. Three cephalopods new to Dorset. Fourn. Conch., Vol. I6, p. 3 I2.

BENEDEN, E. VAN, I883. Compte rendu sommaire des recherches entreprises à la station biologique d'Ostende pendant les mois d'été r883. Bull. Acad. Roy. Sci. Lettres et Beaux-Arts Belg., T. 6, No. II, pp. 458-83.

1 Daily Telegraph, I9 January 1950. 
BianCO, S. Lo, I909. Notizie biologiche riguardanti specialmente il periodo di maturità sessuale degli animali del Golfo di Napoli. Mitth. zool. stat. Neapel, Bd. 19, pp. 513-76r.

CARruthers, J. N., I927. Investigations upon water movements in the English Channel. Summer, 1924. Fourn. Mar. Biol. Assoc., Vol 14, pp. 685-721.

CRAWSHAY, L. R., I9I2. On the fauna of the western outer area of the English Channel. Fourn. Mar. Biol. Assoc., Vol. 9, pp. 292-393.

DARBISHER, R. D., I886. Report on the testaceous Mollusca of the L.M.B.C. district. Liv. Mar. Biol. Comm. Rep., Vol. I, pp. 232-66.

Dautzenberg, Ph. \& Durouchoux, P., I9I3. Les mollusques de la baie de SaintMalo. Feuille des feunes Naturalistes. Paris.

Dautzenberg, Ph. \& Fischer, P. H., I925. Les mollusques marines du Finistère et en particulier de la région de Roscoff. Trav. Stat. Biol. Roscoff, Fasc. 3, pp. I-I80.

Fischer-PIETTE, E., I936. Études sur la biogéographie intercotidale des deux rives de la Manche. Fourn. Linn. Soc., London, Vol. XL, pp. I8I-272.

Forbes, E. \& Hanley, S., I853. A History of British Mollusca. Vol. Iv. London.

Garstang, W., I894. Faunistic notes at Plymouth during 1893-4. Fourn. Mar. Biol. Assoc., Vol. 3, pp. 210-35.

- 1900. The plague of Octopus on the South Coast and its effect on the crab and lobster fisheries. Fourn. Mar. Biol. Assoc., Vol. 6, pp. 260-73.

Giard, A., I885. Synopsis de la fauna marine de la France septentrionale. Bull. Sci. Départ. Nord, I884-5, Nos. 9-10, pp. 293-313.

Gravely, F. H., I908. Notes on the spawning of Eledone and on the occurrence of Eledone with suckers in double rows. Mem. Manchester Lit. Phil. Soc., Vol. 53, No. 4, pp. I-I4; 2 pls.

Grimpe, G., I925. Zur Kenntnis der Cephalopodenfauna der Nordsee. Wiss. Meeresuntersuch. Helgoland, Bd. XvI, No. 3, pp. I-I24.

HADDON, A. C., I886. Recent contributions to the marine invertebrate fauna of Ireland. Zoologist, Ser. 3, Vol. I0, pp. I-7.

Heldi, J. H., I948. Observations sur une ponte d'Octopus vulgaris Lmk. Bull. Soc. Sci. Nat. Tunisie, T. I, Fasc. 2, pp. 87-90.

Herdman, W. A., I893. Oyster-culture and temperature. Nature, Vol. 48, p. 269.

Hertling, H. I936. Mitteilungen über Todaropsis eblanae (Ball), Octopus vulgaris L. und Eledone cirrosa (Lam.) aus der Nordsee. Zool. Anz. Bd. II4, Nr. II/I2, pp. 289-96.

HoyLe, W. E., I886. Notes on the Cephalopoda collected by the L.M.B.C. during the summer of 1885. Liv. Mar. Biol. Comm. Rep., Vol. I, pp. 278-80.

IsGrove, A., I909. Eledone. L.M.B.C. Memoir XVIII. Liverpool.

KeRville, H. GAdeAU DE, I894. Recherches sur les faunas marine et maritime de la Normandie. Ier voyage. Région de Granville et Ile Chausey (Manche) JuilletAoût I893. Bull. Soc. Amis Sci. Nat. Rouen, I894, pp. 55-I26.

- I898. Recherches sur les faunas marine et maritime de la Normandie. ze voyage. Région de Grandcamp-les-Bains (Calvados) et Îles Saint-Marcouf (Manche) Juillet-Septembre I894. Bull. Soc. Amis Sci. Nat. Rouen, 1897, pp. 3II-87.

- 190I. Recherches sur les faunas marine et maritime de la Normandie. 3e voyage. Région d'Omonville la Rogue (Manche) et fosse de la Hague. Bull. Soc. Amis Sci. Nat. Rouen, I900, pp. I45-224.

LEE, H., I875. The Octopus or the 'devilfish' of fiction and of fact. London.

LoE, A. DE \& RAEYMAeKers, D., I885. Recherches Malacologiques.-A l'embouchure de la Somme à Saint-Vallery, au Crotoy, au bourg d'Ault, à Mers et au Tréport. Bull. Sci. Depart. Nord, I884-5, No. 6, pp. 209-48. 
Marine Biological Association, 1931. Plymouth Marine Fauna. (2nd ed.)

MASSY, A. L., 1909. The Cephalopoda dibranchiata of the coasts of Ireland. Fisheries Ireland Sci. Invest., 1907, No. I, 39 pp.

NAEF, A., I921, 1923, I928. Die Cephalopoden. Fauna el Flora del Golfo di Napoli. Vol. 35, Parts I, II and III.

PICKFord, G. E., I945. Le Poulpe americain: a study of the littoral Octopoda of the Western Atlantic. Trans. Connect. Acad. Arts E Sci., Vol. 36, pp. 70I-8I I.

- I950. A note on the eggs of Octopus vulgaris Lam. from the Western Atlantic: the identity of Tandy's eggs from the Dry Tortugas. Proc. Malac. Soc., Vol. 28, pp. 88-92.

Portmann, A., I933. Observations sur la vie embryonnaire de la pieuvre (Octopus vulgaris Lam.). Arch. Zool. Exp. Gén., T. 76, pp. 24-35.

QueRNER, F. R. vON, I926. Die Köllikerschen Buschel jugendlicher Octopoden nebst einigen Bemerkungen sur Histologie der Haut dieser Formen. Zeits. Zellforsch. Mikro. Anat., Bd. 4, p. 237.

Racovitza, E. G., I894. Notes de Biologie. I. Accouplement et fecondation chez l'Octopus vulgaris Lam. Arch. Zool. Exp. Gén. T. 2, pp. 23-49.

Robson, G. C., I929. A monograph of the recent Cephalopoda. Part I. Octopodinae. London.

Russell, F. S., 1939. Hydrographical and biological conditions in the North Sea as indicated by plankton organisms. Fourn. Conseil, Vol. I4, pp. I71-92.

SASAKI, MADOKA, I929. A monograph of the dibranchiate cephalopods of Japanese and adjacent waters. Fourn. Coll. Agric., Hokk. Imp. Univ., Vol. xx, Suppl. No., pp. I-357.

Stephen, A. C., 1937. Notes on Scottish cephalopods. Scot. Nat., I937, pp. I3I-2.

Tesch, J. J., I908. Bijdragen tot de Fauna der Zuidelijke Noorszee. III. Cephalopoda ten deele verzameld met de 'Wodan'. Faarbock van het Rijksinstituut voor het onderzock der zee.

WinckWorth, R., I928. The hectocotylus of Octopus octopodia (L.). Proc. Malac. Soc., Vol. 18, 49-50.

\section{EXPLANATION OF PLATES}

\section{Plate I}

Eggs of the Common Octopus (Octopus vulgaris Lamarck) spawned in an aquarium tank at Plymouth, March 1947. The strings of eggs hang from the roof of a small cave just large enough to contain the octopus. They were found and photographed when the tank was drained for cleaning.

Plate II

Figs. I-4. O. vulgaris Lamarck; larvae from the English Channel; del G.L.W. Fig. I. Dorsal view of larva of $2.4 \mathrm{~mm}$. in ventral mantle length. Fig. 2. Ventral view of same specimen. Fig. 3. Dorsal view of larva of $3.15 \mathrm{~mm}$. in ventral mantle length. Fig. 4. Lateral view of larva of $3.75 \mathrm{~mm}$. in ventral mantle length.

\section{Plate III}

Figs. 5-8. O. vulgaris Lamarck; the largest larva, St. 72, 30. viii. 49; del G.L.W. Fig. 5. Dorsal view. Fig. 6. Oral face of web and tentacles. Fig. 7. Ventral view. Fig. 8. Enlarged view of arm suckers. 






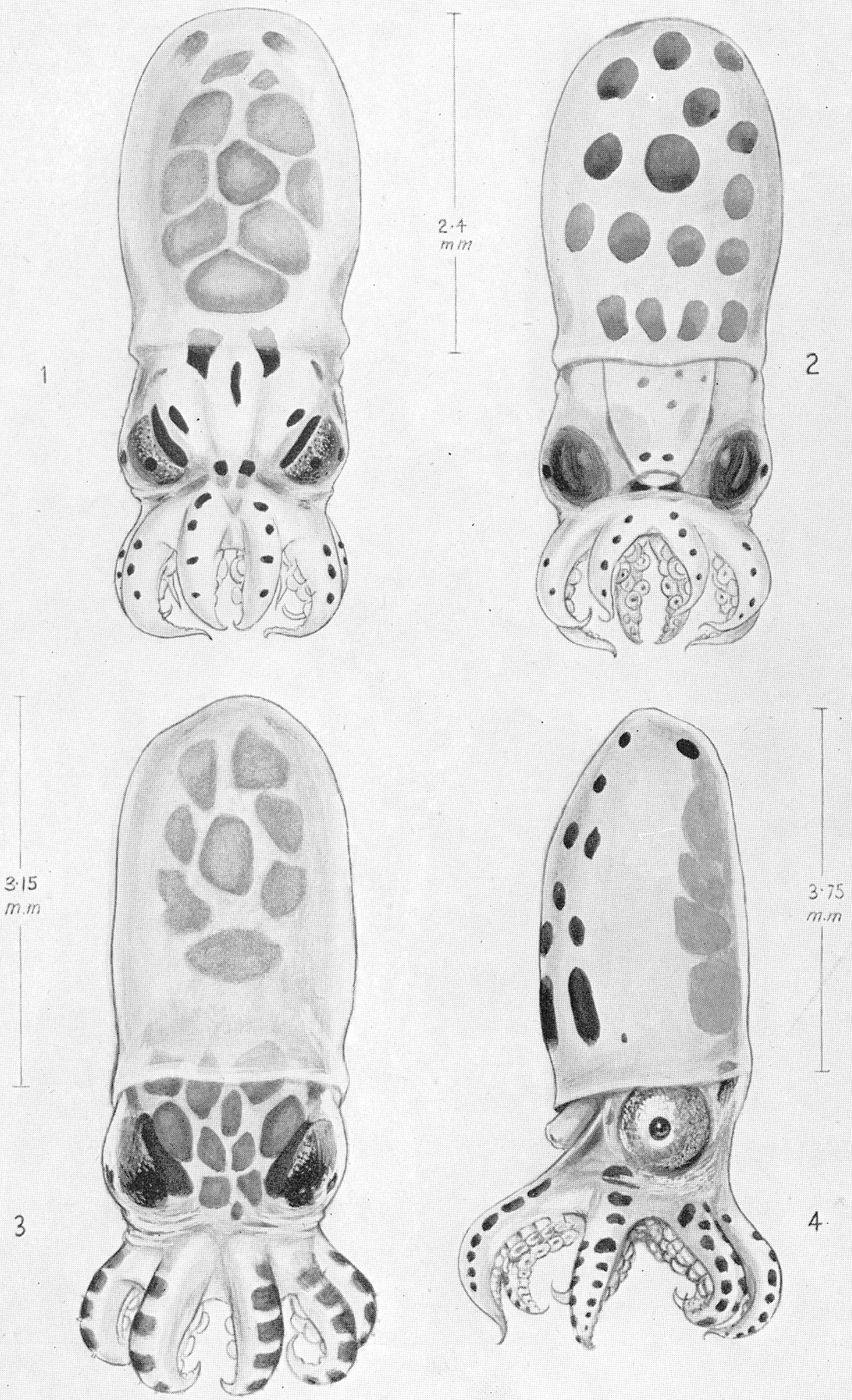




Figs. 5-8. 